\title{
The microstructural record of porphyroclasts and matrix of partly serpentinized peridotite mylonites - from brittle and crystal-plastic deformation to dissolution-precipitation creep
}

\author{
J. Bial ${ }^{1}$ and C. A. Trepmann ${ }^{2}$ \\ ${ }^{1}$ Institut für Geowissenschaften, Abteilung Mineralogie - Petrologie, Universität Kiel, Ludewig-Meyn-Str. 10, \\ 24098 Kiel, Germany \\ ${ }^{2}$ Department für Geo- und Umweltwissenschaften, Ludwig-Maximilians-Universität München, Luisenstraße 37, \\ 80333 Munich, Germany \\ Correspondence to: J. Bial (jb@min.uni-kiel.de)
}

Received: 19 March 2013 - Published in Solid Earth Discuss.: 12 April 2013

Revised: 6 August 2013 - Accepted: 22 August 2013 - Published: 11 October 2013

\begin{abstract}
We present microfabrics in high-pressure, metamorphic, partly serpentinized peridotite mylonites from the Voltri Massif, in which porphyroclasts and matrix record independent deformation events. The microfabrics are analysed using polarization microscopy and electron microscopy (SEM/EBSD, EMP). The mylonites contain diopside and olivine porphyroclasts originating from the mantle protolith embedded in a fine-grained matrix consisting mainly of antigorite and minor olivine and pyroxene. The porphyroclasts record brittle and crystal-plastic deformation of the peridotite at upper-mantle conditions and differential stresses of a few hundred MPa. After the peridotites became serpentinized, deformation occurred mainly by dissolutionprecipitation creep resulting in a pronounced foliation of the antigorite matrix, crenulation cleavages and newly precipitated olivine and pyroxene from the pore fluid at sites of dilation, i.e. in strain shadows next to porphyroclasts and folded fine-grained antigorite layers. Antigorite reveals a pronounced associated shape preferred orientation (SPO) and crystallographic preferred orientation (CPO) with the basal (001) cleavage plane oriented in the foliation plane. In monomineralic antigorite aggregates at sites of stress concentration around porphyroclasts, a characteristically reduced grain size and deflecting $\mathrm{CPO}$ as well as sutured grain boundaries indicate also some contribution of crystal-plastic deformation and grain-boundary migration of antigorite. In contrast, the absence of any intragranular deformation features in newly precipitated olivine in strain shadows reveals
\end{abstract}

that stresses were not sufficiently high to allow for significant dislocation creep of olivine at conditions at which antigorite is stable. The porphyroclast microstructures are not associated with the microstructures of the mylonitic matrix, but are inherited from an independent earlier deformation. The porphyroclasts record a high-stress deformation of the peridotite with dislocation creep of olivine in the upper mantle probably related to rifting processes, whereas the serpentinite matrix records dominantly dissolution-precipitation creep and low stresses during subduction and exhumation.

\section{Introduction}

In mylonites, the microstructures of porphyroclasts and mylonitic matrix are commonly associated and develop concurrently, though by different deformation mechanisms (e.g. Mitra, 1978; White et al., 1980; Schmid and Handy 1990; Handy et al., 1999). Here, we present microstructures in partly serpentinized peridotite mylonites from the Voltri Massif, in which porphyroclasts and matrix record independent deformation events. The ophiolitic rocks from the Alpine Voltri Massif, northwestern Italy, provide a unique record of their complex geodynamic history. As such, these rocks have been studied extensively by petrological, structural and geochronological investigations (e.g. Drury et al., 1990; Vissers et al., 1991, 1995; Hoogerduijn Strating, 1991; Hoogerduijn Strating and Vissers, 1991; 
Hoogerduijn Strating et al., 1993; Hermann et al., 2000; Rampone et al., 2005; Piccardo, 2003, 2008, 2010; Healy et al., 2009; Vignaroli et al., 2010; Malatesta et al., 2012a, b); see Piccardo (2013) for a recent review on the geodynamic history of the Voltri Massif. In the variously serpentinized, high-pressure, metamorphic peridotites from the Voltri Massif, the original mantle components are in parts still preserved. As such they carry information on the pre-Alpine evolution (e.g. Drury et al., 1990; Hoogerduijn Strating 1991; Hoogerduijn Strating et al., 1993; Vissers et al., 1991; Rampone et al., 2004, 2005; Piccardo and Vissers, 2007), as well as on the subsequent subduction and exhumation history (e.g. Scambelluri et al., 1991, 1995, 1997; Messiga et al., 1995; Hermann et al., 2000; Früh-Green et al., 2001; Malatesta et al., 2012a, b; Piccardo 2013).

In this study, we focus on the so far not widely used microstructural record of grain-scale deformation processes provided by partly serpentinized peridotite mylonites (Drury et al., 1990; Hoogerduijn Strating, 1991; Scambelluri et al., 1991; Hoogerduijn Strating and Vissers, 1991; Hoogerduijn Strating et al., 1993; Vissers et al., 1991, 1995; Hermann et al., 2000) to obtain information on the rheology and the stress condition during the different deformation stages. These rocks dramatically changed their mineral content and thus their rheological behaviour during the complex geodynamic history. In comparison with experimental studies on the rheology of rock-forming minerals in metamorphic mafic to ultramafic rocks (olivine: e.g. Chopra and Paterson, 1981; Hirth and Kohlstedt, 2003; Zhang et al., 2000; Jung and Karato, 2001; Jung et al., 2006; Druiventak et al., 2011, 2012; clinopyroxene: e.g. Avé Lallemant, 1978; Ingrin et al., 1992; Orzol et al., 2006; Zhang et al., 2006; Zhang and Green, 2007; Moghadam et al., 2010; antigorite: e.g. Hilairet et al., 2007; Chernak and Hirth, 2010) microfabrics can yield information on the deformation mechanisms, as well as the stress and strain-rate conditions during burial and exhumation (e.g. Skrotzki et al., 1990; van der Wal, 1993; Altenberger, 1995; Jin et al. 1998; Zhang et al, 2000; Jung and Karato, 2001; Piepenbreier and Stöckhert, 2001; Stöckhert, 2002; Andreani et al., 2005; Auzende et al., 2006; Jung et al., 2006; Wassmann et al., 2011; Matysiak and Trepmann, 2012). The aim of this study is to use the successively overprinted and modified microfabrics of the partly serpentinized peridotite mylonites to differentiate between the potential record of independent grain-scale deformation processes and implications on the stress conditions. On the basis of the findings we discuss implications for the inferred superposition of features associated with initial brittle and crystal-plastic deformation of the original mantle peridotites with features indicating dissolution-precipitation creep of the serpentinized peridotites.

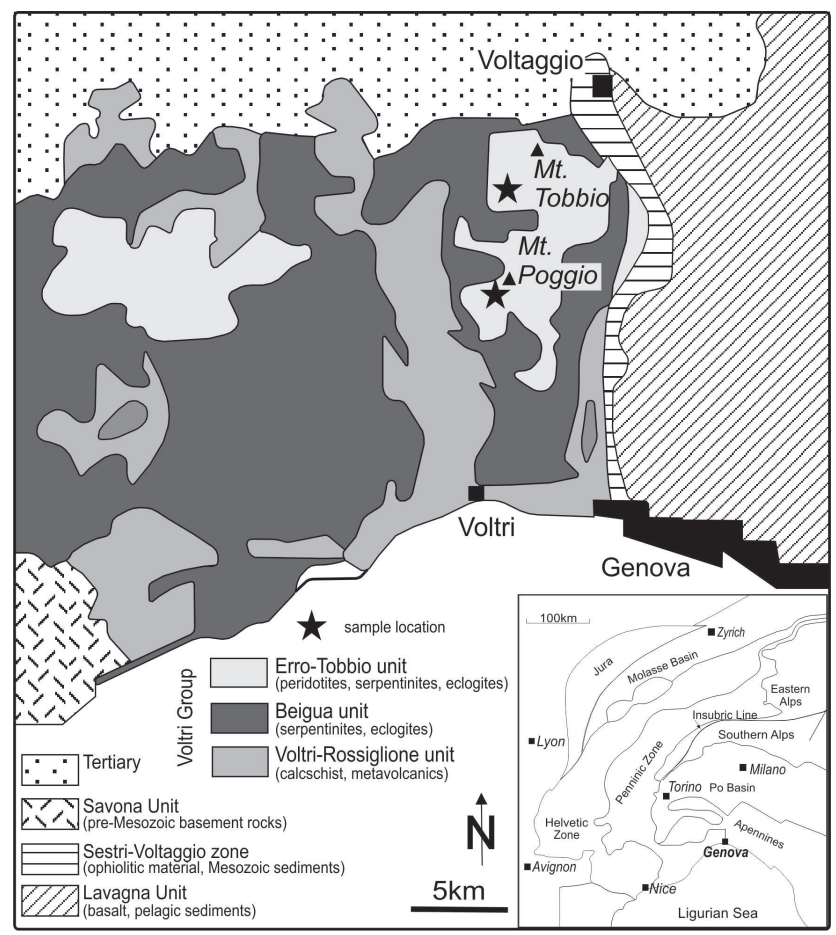

Fig. 1. Schematic tectonic map of the Voltri Group (after Scambelluri et al., 1991). Serpentinites have been sampled close to Mt. Tobbio and Mt. Poggio as indicated by the star.

\section{Geological setting}

The ophiolitic Voltri Massif is located in NW Italy, about $20 \mathrm{~km} \mathrm{NW}$ of Genoa directly at the transition from the Ligurian Alps to the Apennine chain (Fig. 1). As the largest ultramafic massif within the Alps-Apennine chain it is restricted eastward by the Sestri Voltaggio Zone and northward by the Piemont basin filled with Tertiary sediments (Hoogerduijn Strating, 1991). The ophiolite complex from the Voltri Massif is related to the Late Jurassic Piemont-Ligurian Ocean, the Alpine-Apennine part of the Mesozoic Tethys (Bodinier et al., 1986; Hoogerduijn Strating, 1991; Scambelluri et al., 1997, 2004; Hermann et al, 2000; Piccardo and Vissers, 2007). The Jurassic Piemont-Ligurian Tethys has been proposed to represent an analogue of a slow-ultraslowspreading ocean basin (Tribuzio et al., 2000; Piccardo, 2008, 2013), which is characterized by extended continental margins and ocean continent transition zones, whereby lithospheric subcontinental mantle can be preserved in the rift system (Manatschal et al., 2007; Péron-Pinvidic and Manatschal, 2009; Piccardo, 2013). The Voltri Massif ophiolite complex comprises units that are derived from oceanic lithosphere (Beigua-type serpentinites), associated with their volcanic-sedimentary cover (Voltri-Rossiglione-type calcschists and meta-volcanics), and units derived from the subcontinental mantle (Erro-Tobbio-type peridotites; $T<$ $1000-1100^{\circ} \mathrm{C}$ and spinel-facies conditions; e.g. Vissers et 
al., 1991; Rampone et al., 2005; Piccardo, 2003, 2008, 2010; Piccardo and Vissers, 2007); for a recent review see Piccardo (2013).

During subduction of the Piemont-Ligurian Ocean and Alpine collision, the Voltri Massif ophiolitic rocks underwent an Alpine prograde metamorphism (Hoogerduijn Strating, 1991; Messiga et al., 1995; Scambelluri et al., 1995; Hermann et al., 2000; Früh-Green et al., 2001; Malatesta et al., 2012a, b). The peak metamorphic conditions of the Alpine metamorphism have been estimated at $1.8-2.5 \mathrm{GPa}$ and $500-650^{\circ} \mathrm{C}$ on the basis of the assemblage omphacite + chloritoid + garnet + zoisite \pm talc in a mylonitic metagabbro by Messiga et al. (1995), which are consistent with the pressure-temperature (P-T) estimates by Scambelluri et al. (1995). Recently performed P-T pseudosections coupled with garnet-omphacite geothermometry reveal peak metamorphic conditions for eclogitic lenses ranging from $2.1 \mathrm{GPa}$ and $450-490^{\circ} \mathrm{C}$ to $2.2-2.8 \mathrm{GPa}$ and $460-500^{\circ} \mathrm{C}$ (Malatesta et al., 2012a). The peak pressure condition indicates a subduction of rocks from the Erro-Tobbio unit up to $80 \mathrm{~km}$ depth (Hermann et al., 2000). New U-Pb SHRIMP data for zircon and titanite ages coupled with $\mathrm{Ar}$-Ar phengite ages show a time interval of $\sim 34$ to $\sim 50 \mathrm{Ma}$ for the eclogite facies peak metamorphism (Rubatto and Scambelluri, 2003; Federico et al., 2005, 2007; Vignaroli et al., 2010). Veins in antigorite serpentinites, containing olivine, titanian clinohumite, magnetite and diopside (Scambelluri et al., 1995) have been interpreted as dehydration cracks generated at high-pressure (HP) conditions and indicating the circulation of a free fluid phase (Hoogerduijn Strating and Vissers., 1991; Scambelluri et al., 2004; Healy et al., 2009). Piccardo (2013) discussed that this formation requires that the Ti-bearing minerals of mantle peridotites crystallize at eclogite facies conditions accompanied by the release of Ti, while appreciable volumes of water were present in this environment. This suggests that $\mathrm{Ti}$ is mobile in fluid phases at eclogite facies conditions (Gao et al., 2007). Field and petrologic evidence indicate that the peridotites of the Erro-Tobbio unit are characterized by a widespread occurrence of Ti-bearing clinohumite; in contrast, the Beigua serpentinites are described to be almost free of Ti-clinohumite (Piccardo, 2013). The most recent literature (Piccardo, 2013; Scambelluri, 2013) discusses whether the Erro-Tobbio peridotites got serpentinized during large-scale hydration at shallow lithospheric depths of the Piemont-Ligurian Tethys by sea-water-derived fluids (Scambelluri et al., 1997; Hermann et al., 2000; Früh-Green et al., 2001; Scambelluri, 2013), as proposed also for the Beigua serpentinites (Piccardo, 2013), or whether the Erro-Tobbio peridotites became hydrated at HP eclogite facies conditions by dehydration fluids of other units of the Voltri Massif (e.g. the Beigua serpentinites) (Piccardo, 2013).

The prograde evolution of the Erro-Tobbio rocks is followed by a retrograde metamorphic history related to Alpine collision (Hoogerduijn Strating, 1991, 1994). The exhumation path for the Voltri HP units reveals a two-stage process consisting of an early synorogenic exhumation within the subduction zone at ca. 33 to $35 \mathrm{Ma}$, during which the rocks are overprinted by a greenschist facies metamorphism, followed by a postorogenic, $<30 \mathrm{Ma}$ exhumation from greenschist facies metamorphic conditions to upper crustal conditions due to crustal thinning, accomplished by a relatively high cooling rate of up to $40^{\circ} \mathrm{C} \mathrm{Ma}^{-1}$ (Vignaroli et al., 2010). The eastern sector of the Voltri Massif has been interpreted as a tectonic mélange in which strongly deformed serpentinites and metasediments enclose variably deformed lenses of HP metagabbro, metabasite, and peridotite, representing a fossil subduction channel (Federico et al., 2007; Malatesta et al., 2012a; Piccardo, 2013). Numerical simulations adapted for the geological situation of the Voltri Massif show that the model of a subduction channel with lowviscosity serpentinites can explain the observations of such a tectonic mélange exhumed from HP conditions (Malatesta et al., 2012a, b). Piccardo (2013) proposed that the ultramafic units of slab (Beigua unit) and mantle-wedge (ErroTobbio unit) provenances were emplaced and exhumed together from deep levels of the subduction channel.

\section{Methods}

Thin sections (ca. $30 \mu \mathrm{m}$ ) were examined with a polarization microscope and analysed with the electron backscattered diffraction (EBSD) method (e.g. Prior et al., 1996, 1999) using the scanning electron microscope (SEM) LEO 1530 at Ruhr University, Bochum (Germany). For EBSD investigations, mechanically polished thin sections have additionally been chemically polished with Syton ${ }^{\circledR}$ for 15 min to reduce surface damage and then coated with carbon to avoid charging effects. For EBSD analysis the thin sections were tilted at an angle of $70^{\circ}$ with respect to the beam. An accelerating voltage of $20 \mathrm{kV}$ and a working distance to $25 \mu \mathrm{m}$ was used. The EBSD data were analysed using the Oxford Instruments HKL software CHANNEL 5. A CAMECA SX-50 electron microprobe was used for the analysis of the chemical mineral composition.

\section{Sample description}

The partly serpentinized peridotite mylonites studied here were collected in NW Italy about $10 \mathrm{~km} \mathrm{NW}$ of Genoa, SW of Mt. Poggio (N 44 $32^{\prime} 0.48^{\prime \prime}$, E $008^{\circ} 46^{\prime} 39.96^{\prime \prime}$ ) and SW of Mt. Tobbio (N 44 31'49.02", E 008 46 38.94 (Fig. 1). The modal composition varies strongly but is typically in the range of $46-51 \%$ antigorite, $10-20 \%$ olivine, 5$10 \%$ diopside, 5-7\% chlorite, 2-3\% spinel, and 0-2\% enstatite. Associated with these partly serpentinized peridotite mylonites, vein-like structures containing Ti-clinohumite are widespread within the sampled area. The occurrence of Ti-clinohumite in the investigated partly serpentinized peridotite mylonites suggests their association with the 


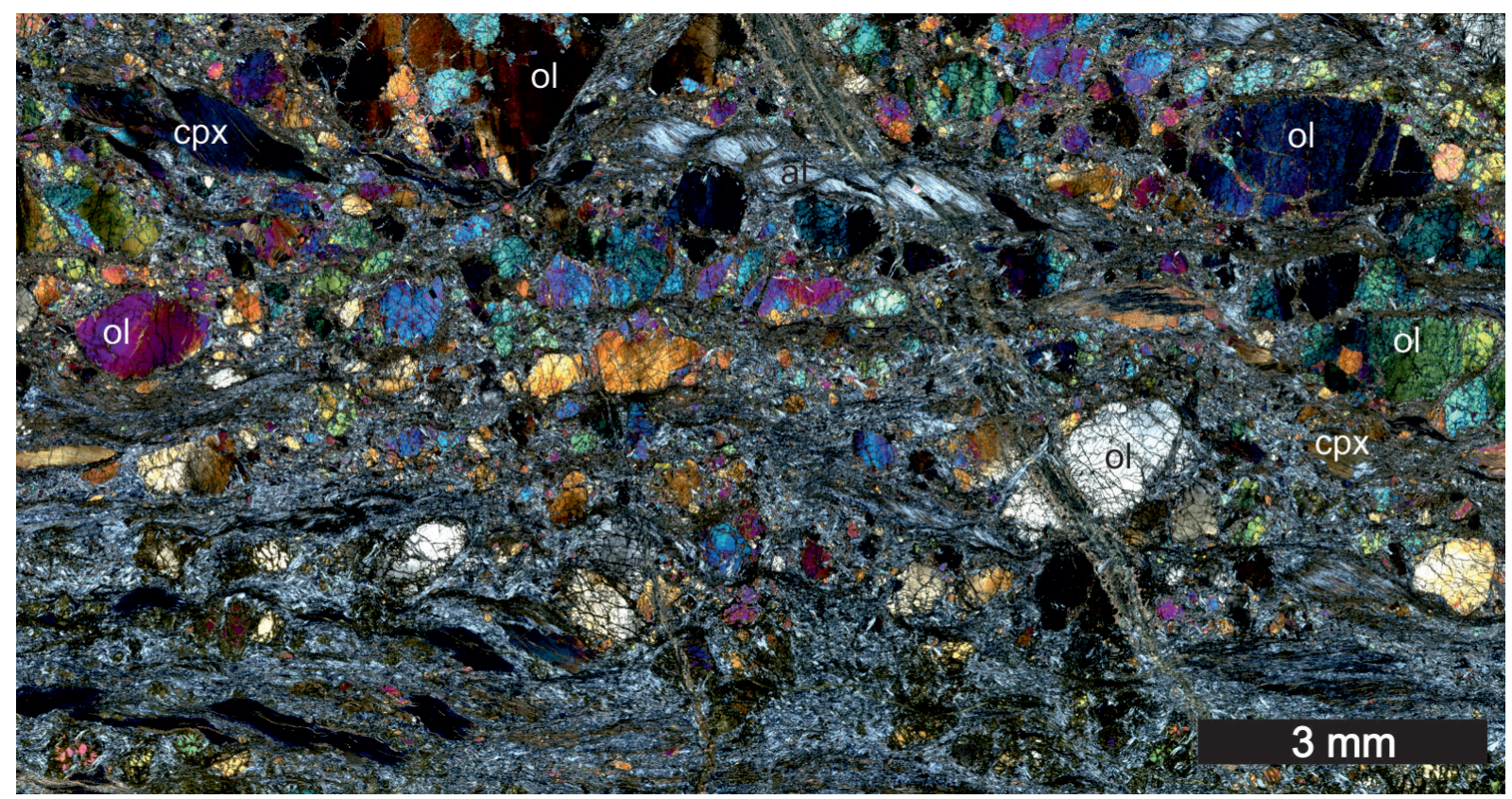

Fig. 2. Polarized light micrograph (crossed polarizers) of a typical sample of investigated partly serpentinized peridotite mylonites. Olivine and clinopyroxene porphyroclasts are embedded in an antigorite-rich matrix (sample CT_07-13).

Erro-Tobbio unit (Hoogerduijn Strating and Vissers., 1991; Piccardo, 2013). However, as discussed by Piccardo (2013), a differentiation of serpentinized Erro-Tobbio peridotites and serpentinites from the Beigua unit can be quite subtle, because of their close field relations and their correlated subduction and exhumation history. Hoogerduijn Strating et al. (1993) distinguished five types of shear zone developed from original granular spinel lherzolites from the ErroTobbio unit by mineral association, namely, spinel-bearing porphyroclastic tectonites; plagioclase-, hornblende-, and chlorite-bearing peridotite mylonites; and serpentinite mylonites. The samples investigated here, correspond to serpentinite mylonites, i.e. chlorite-bearing partly serpentinized peridotite mylonites. Although a variety of mesoscopic structures in the ultramafic rocks of the Voltri Massif unit has been interpreted to pre-date Alpine thrust zones, they are widely modified by the Alpine deformation and metamorphism (e.g. Drury et al., 1990; Hoogerduijn Strating, 1991; Hoogerduijn Strating and Vissers, 1991; Hoogerduijn Strating et al., 1993; Scambelluri et al., 1991, 1995). This is especially true for partly serpentinized peridotite mylonites studied here. All investigated serpentinites show a pervasive slaty cleavage and a variously pronounced lineation characterized by a shape preferred orientation (SPO) of antigorite and magnetite. In this study, we focus on the microstructural record of the rocks to infer the grain-scale deformation processes. Thin sections are oriented perpendicular to foliation (i.e. parallel to the maximum shortening direction $z$ ) and parallel to lineation (minimum shortening direction $x$ ), if present. In thin sections, the foliation is defined by antigorite-rich layers with a SPO of the grains. Antigorite forms a matrix in which large isolated olivine and diopside porphyroclasts are embedded (Fig. 2).

\section{Microfabrics}

\subsection{Porphyroclasts}

The olivine porphyroclasts have an average grain diameter of $1.2 \mathrm{~mm}$ (Fig. 2). They show undulatory extinction, deformation bands, low-angle grain boundaries (LAGBs) forming chess-board-like patterns and irregular subgrains (Fig. 3a-c). Olivine porphyroclasts are partly recrystallized: the recrystallized grains occur in intragranular bands (Fig. 3c, d) or along the boundary of porphyroclasts (Fig. 3e, f). The size of the recrystallized grains is typically in the range of 10 to $50 \mu \mathrm{m}$. The boundaries of recrystallized grains are mostly smoothly curved and only slightly lobate (Figs. 4a, b, 5a, b). Low-angle grain boundaries (yellow lines in Fig. 4a) in the porphyroclasts show a similar isometric shape and size as compared to the new grains (red lines in Fig. 4a). The crystallographic orientation of the recrystallized grains scatters around the crystallographic orientation of the host (Fig. 4c, d, $5 \mathrm{c}, \mathrm{d})$. The olivine porphyroclasts consist of $\mathrm{Fo}_{90-87}$ with an average composition of $\mathrm{Mg}_{1.8} \mathrm{Fe}_{0.2} \mathrm{SiO}_{4}$. In comparison, recrystallized grains have a lower $\mathrm{X}_{M g}$ with an average composition of $\mathrm{Mg}_{1.7} \mathrm{Fe}_{0.3} \mathrm{SiO}_{4}$ in the range of Fo87-85 (Fig. 5). No chemical zoning in single grains is apparent (Fig. 5). The undulatory extinction of olivine porphyroclasts observed by polarization microscopy (Fig. 3) is represented in EBSD maps 
by relative misorientation angles of up to $30^{\circ}$ (Figs. $4 \mathrm{a}$ and 5a).

Large diopside porphyroclasts occur in the partly serpentinized peridotite mylonites embedded in the antigorite matrix with an average grain diameter of ca. $2 \mathrm{~mm}$. (Figs. 2, 6). The average composition is $\left(\mathrm{Mg}_{0.9}, \mathrm{Fe}_{0.1}, \mathrm{Ca}_{0.9}, \mathrm{Al}_{0.1}\right)\left[\left(\mathrm{Si}_{1.9}, \mathrm{Al}_{0.1}\right) \mathrm{O}_{6}\right]$. All diopside porphyroclasts show exsolution lamellae parallel (100) with a relative constant spacing and a width of a few $\mu \mathrm{m}$ (Fig. 6). They are commonly fractured (Fig. 6a), kinked and bent (Fig. 6b, c). The stereographic projection of bent and kinked crystals shows that the [010] axis is a common axis and thus probably represents the rotation axis (i.e. the normal to the glide direction within the glide plane) during deformation by dislocation glide (Fig. 6c). The misorientation angle between kinked domains is in the range of $50^{\circ}$ to $70^{\circ}$ (Fig. 6c). The progressive misorientation within a bent kink domain is characterized by a misorientation angle of up to $60^{\circ}$ (Fig. 6d).

\subsection{Matrix}

Some of the olivine porphyroclasts embedded in the matrix show asymmetric strain shadows (Fig. 2), in which finegrained olivine $(20-40 \mu \mathrm{m}$ in diameter) and antigorite aggregates (Fig. 7b, c) occur. In these aggregates antigorite grains are elongate (long axis: $200-400 \mu \mathrm{m}$ ) and show rare grain boundaries. Instead, unilateral rational phase boundaries parallel to the antigorite cleavage plane, i.e. the (001) basal plane, to fine-grained olivine dominate (Fig. 7c). The antigorite (001) basal plane is oriented parallel to the foliation plane, as shown in polarized light micrograph Fig. $7 \mathrm{~b}$ and EBSD map Fig. 7c, revealing that the SPO is associated with a crystallographic preferred orientation (CPO). Also the olivine grains show a SPO in strain shadows by a preferred 2-D orientation of the long axis parallel to the foliation of the sample (Fig. 7c, f). The size of the olivine grains in the strain shadow ranges from 5 to $60 \mu \mathrm{m}$. Their composition is, with Fo82-86, lower in Mg compared to olivine porphyroclasts and recrystallized olivine. In strain shadows around diopside porphyroclasts, aggregates of diopside and enstatite occur (Fig. 7a). The new pyroxene crystals in the strain shadows do not show any exsolution lamellae, in contrast to the porphyroclasts.

Antigorite occurs as long needles growing into olivine porphyroclasts (Figs. 3-5, 8a), together with olivine in strain shadows (Fig. 7b, c) and in fine-grained antigorite-rich layers. The fine-grained antigorite layers show a pronounced associated SPO and CPO obvious from the polarized light micrographs with crossed polarizers (Fig. 8a, b) and with inserted compensator (Fig. 8c, d) showing the antigorite cleavage plane, i.e. (001) basal plane, parallel to the foliation plane. The fine-grained antigorite layers can be folded, forming a crenulation cleavage with fine-grained secondary olivine enriched in shear bands (Fig. 8a, b). The size of antig- orite grains in monomineralic aggregates is smaller in the vicinity of porphyroclasts at sites of stress concentrations, where also the CPO is deflected (Fig. 8c, d). Furthermore, antigorite grains in monomineralic aggregates show sutured grain boundaries (Fig. 8e, d).

\section{Discussion}

\subsection{Deformation processes and conditions recorded by olivine and diopside porphyroclasts}

The deformed diopside porphyroclasts (Fig. 6) record brittle and crystal-plastic deformation by dislocation glide. The bent (100) plane, the common rotation axis and kink band axis parallel to [010] indicate that the glide system (100) [001] was active. Mechanical twinning of clinopyroxene is known to occur by the activation of the same glide system (100) [001] (e.g. Raleigh and Talbot, 1967; Kirby and Christie, 1977). It requires a critical shear stress on the (100) glide plane of about 140 to $150 \mathrm{MPa} \pm 50 \mathrm{MPa}$ and therefore high differential stresses of at least 280 to $300 \mathrm{MPa}$ (Kolle and Blacic 1982; Trepmann and Stöckhert, 2001; Orzol et al., 2003). No mechanical twins are observed in the diopside porphyroclasts. Yet, the overall presence of (100) exsolution lamellae in porphyroclasts may have masked or inhibited (100) twinning. As recrystallized grains and subgrains in diopside porphyroclasts are characteristically absent, there is no evidence for dislocation climb and dynamic recrystallization. The dislocation-glide-controlled diopside microstructures described here are consistent with observations of experimentally and naturally deformed clinopyroxene from previous studies that show the dominance of kinking and dislocation glide over dislocation climb processes, with the system for gliding being predominantly (100) [001] (e.g. Green and Radcliffe, 1972; Skemer et al., 2006; Skrotzki et al., 1990; Moghadam et al., 2010). Dynamically recrystallized pyroxenes are reported from nature to occur localized at high stresses (e.g. Müller and Franz, 2008; Raimbourgh et al., 2008 ) and temperatures as low as $500^{\circ} \mathrm{C}$ (e.g. Piepenbreier and Stöckhert, 2001), consistent with experimental studies (e.g. Orzol et al., 2006; Zhang et al., 2006; Zhang and Green, 2007; Moghadam et al., 2010). Thus, the systematic absence of recrystallized grains, subgrains and twins in diopside suggest that stresses were not sufficiently high to allow for effective dynamic recrystallization and mechanical twinning of diopside. Dislocation glide, kinking and fracturing are the dominant deformation mechanisms recorded by the diopside porphyroclasts.

The intragranular deformation microstructures in olivine porphyroclasts (undulatory extinction, deformation bands, LAGBs) indicate inhomogeneous crystal-plastic deformation with dislocation glide and dislocation climb (Fig. 3). The intragranular zones with recrystallized small grains show a crystallographic orientation similar to that of the 

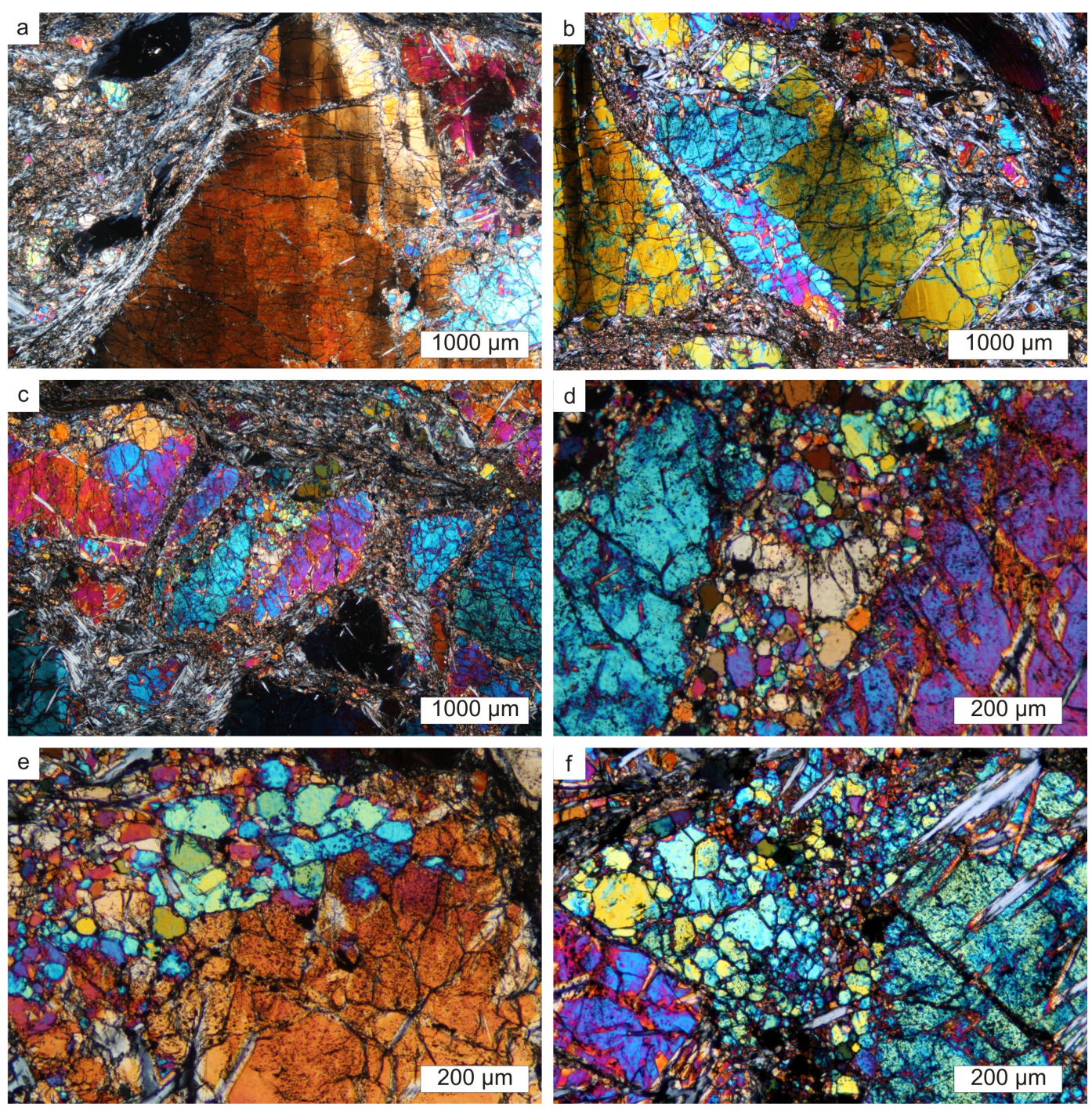

Fig. 3. Polarized light micrograph (crossed polarizers) showing microstructures in olivine porphyroclasts from sample CT_07-13. (a, b) Deformation bands and subgrains in olivine porphyroclasts; $(\mathbf{c}, \mathbf{d})$ intragranular zones of recrystallized olivine grains within olivine porphyroclast; (e, f) partly recrystallized olivine porphyroclasts. EBSD map of area in $\mathrm{f}$ is presented in Fig. 4.

host porphyroclast. The porphyroclasts show many subgrains (Fig. 4) with a similar size and shape compared to the recrystallized grains (Figs. 3c-f, 4, 5). Both observations suggest subgrain rotation recrystallization in the regime of dislocation creep, where the new grains inherit a crystallographic orientation similar to that of the replaced original grain (e.g. Nicolas and Poirier, 1976; Poirier, 1985; Urai et al., 1986; Drury and Urai, 1990; Lloyd and Freeman, 1994; Bestmann and Prior, 2003; Trepmann and Stöckhert, 2009). Some influence of grain-boundary migration, however, is not excluded as the grain boundaries of recrystallized grains can be slightly lobate (Figs. 4a, b, 5 a, b). Jung and Karato (2001) discuss that grain-boundary migration in olivine is facilitated by the presence of fluids, as is well known e.g. also for quartz (e.g. Drury and Urai, 1990; Mancktelow and Pen- nacchioni, 2004). Growth of new grains along former microcracks is suggested by intragranular zones of recrystallized grains that show a systematic chemical variation to the host porphyroclast. The different chemical composition of olivine porphyroclasts and intragranular new grains indicates the involvement of chemical reactions during recrystallization. A secondary chemical variation caused by the larger surface area in relation to the grain volume of the recrystallized grains seems unlikely, as the porphyroclasts do not show any chemical variation at their phase boundary to the antigorite matrix. Chemical reactions during dislocation creep are known to be able to cause chemical variation of recrystallized grains (e.g. Yund and Tullis, 1991; Stünitz, 1998; Büttner and Kasemann, 2007). The observed decrease in the $X_{\mathrm{Mg}}$ values in intragranular recrystallized zones requires an 


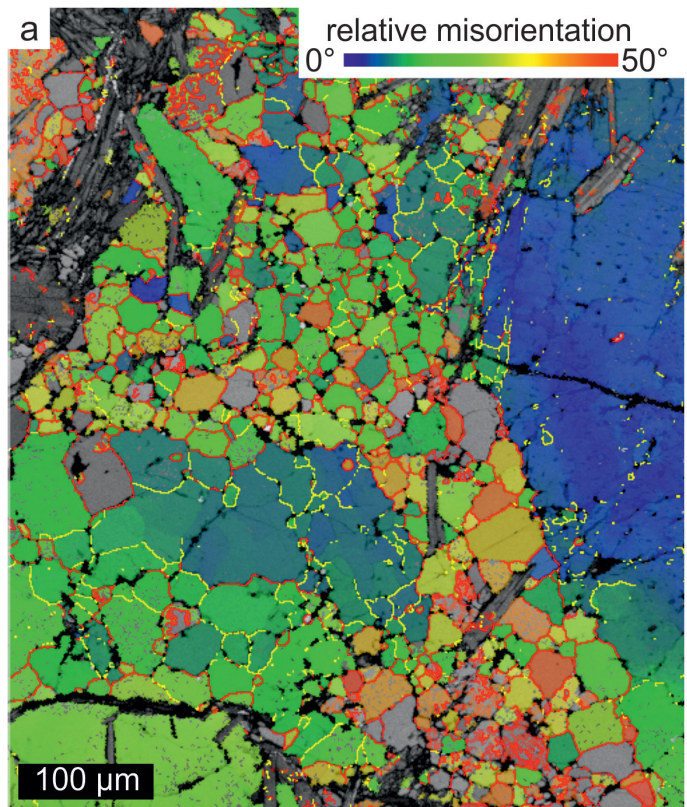

C Porphyroclast

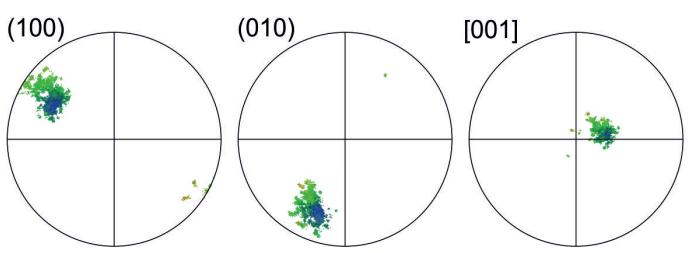

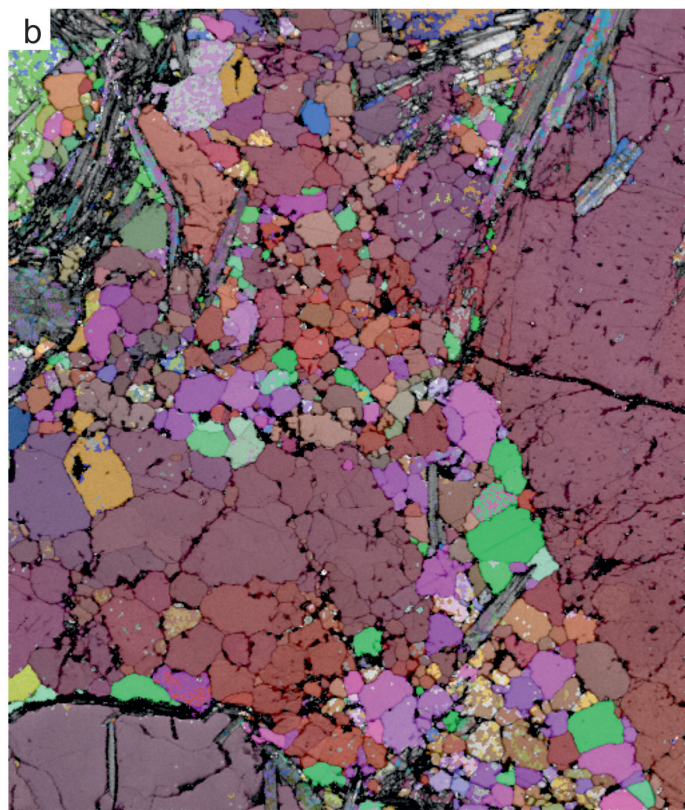

d Recrystallized grains
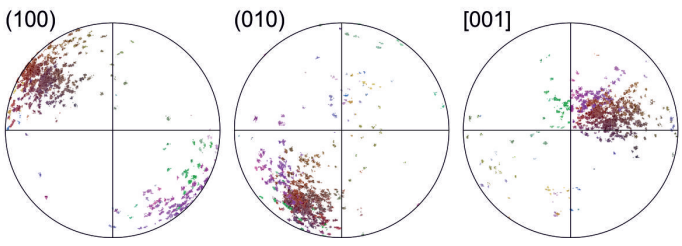

Fig. 4. EBSD data presented as maps colour-coded by (a) the relative misorientation and (b) orientation (Euler angles) showing partly recrystallized olivine porphyroclast (sample CT_07-13; compare Fig. 3f). Yellow lines in (a) represent low-angle grain boundaries (misorientation $<10^{\circ}$ ); red lines represent high-angle grain boundaries (misorientation $>10^{\circ}$ ). (c, d) Corresponding pole figures of poles to $(100)$, $(010)$ and (001) planes in an equal-angle projection of the lower hemisphere for porphyroclasts and recrystallized grains, respectively.

exchange reaction between olivine and a co-existing solid or fluid phase, both being favoured by the presence of a circulating free fluid. Localized intragranular zones of recrystallized grains within deformed porphyroclasts suggest that recrystallization was restricted at sites of high strain, e.g. along former fractures, kink bands and deformation bands. Such deformation features have been observed from naturally deformed peridotites from the Balmuccia complex in the Western Alps (Matysiak and Trepmann, 2012) and by deformation and annealing experiments on peridotites (Druiventak et al. 2012). Intragranular zones of recrystallized grains within deformed porphyroclasts are indicators for a switch from an initial brittle and glide-controlled deformation in the lowplasticity regime followed by dislocation creep. Such a microstructural development is characteristic for stress variations at the lower tip of seismically active fault zones (Trepmann and Stöckhert, 2003; Trepmann et al., 2007; Druiventak et al., 2012; Matysiak and Trepmann, 2012). However, the chemical variance of recrystallized grains and host porphyroclasts observed here is in contrast to the remarkably homogeneous chemical composition of the localized recrystal- lized grains and porphyroclasts in peridotites from the Ivrea zone (e.g. Matysiak and Trepmann, 2012).

Applying the experimental calibrations of the dependence of recrystallization grain size of olivine developed in the regime of dislocation creep on flow stress by van der Wal et al. (1993) and Karato (1980) to the observed recrystallized grain sizes of 10 to $50 \mu \mathrm{m}$, one derives differential stresses in the range of 70 to $250 \mathrm{MPa}$ and 76 to $300 \mathrm{MPa}$, respectively. As grain-boundary migration may have modified recrystallized grain size, and given the large uncertainties of the extrapolations of the experimental results to nature, these values can only be considered to give a rough order of magnitude. Differential stresses not markedly exceeding $300 \mathrm{MPa}$ are consistent with the absence of recrystallized and twinned diopside.

The absence of serpentine minerals in the intragranular recrystallized olivine aggregates within olivine porphyroclasts implies temperatures higher than $600^{\circ} \mathrm{C}$ (e.g. Hermann et al., 2000; Scambelluri et al., 2004) during recrystallization. A temperature above $600^{\circ} \mathrm{C}$ is also in accord with the general assumption that dynamic recrystallization of olivine in 

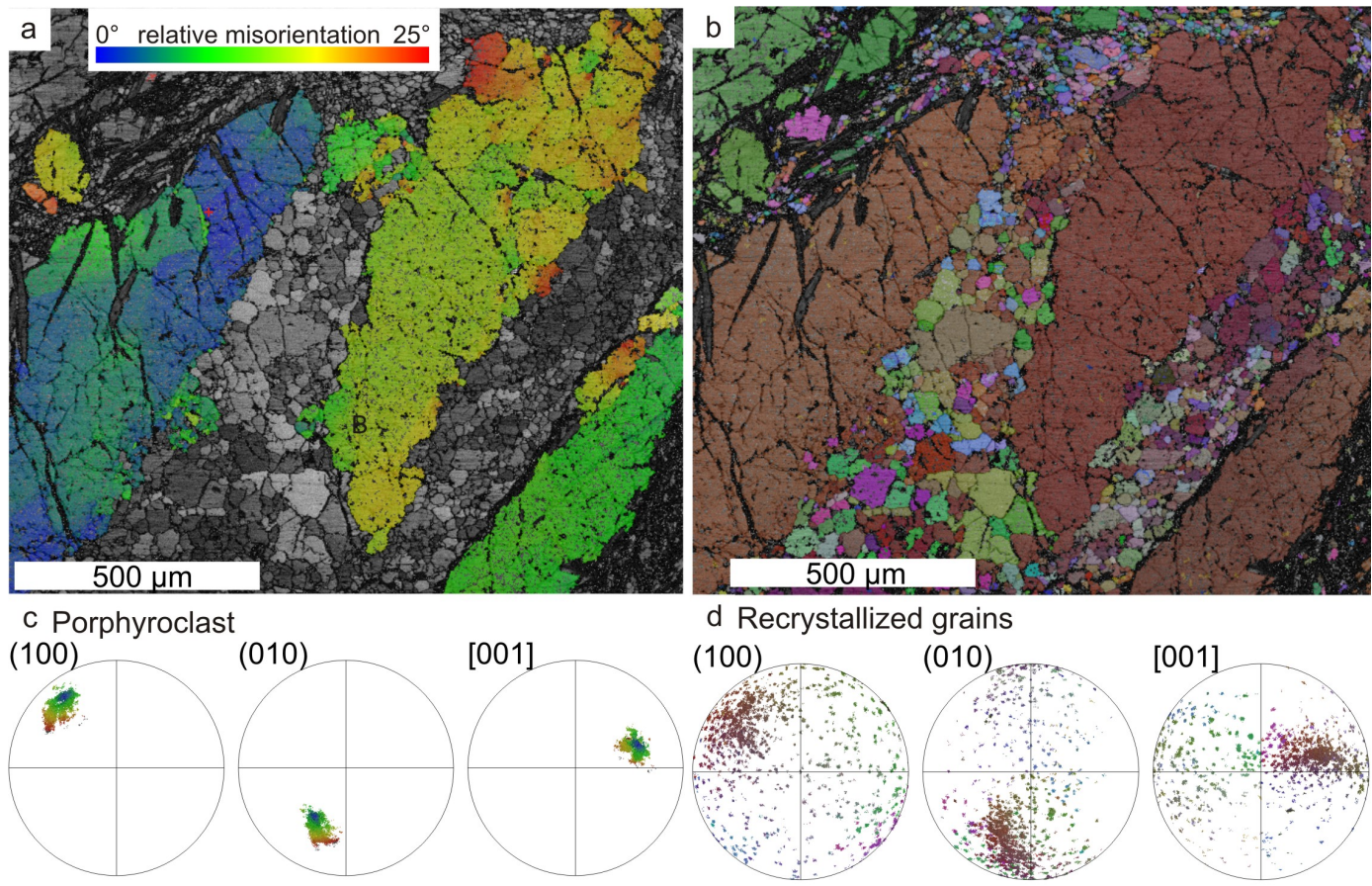

d Recrystallized grains

(100)

(010)
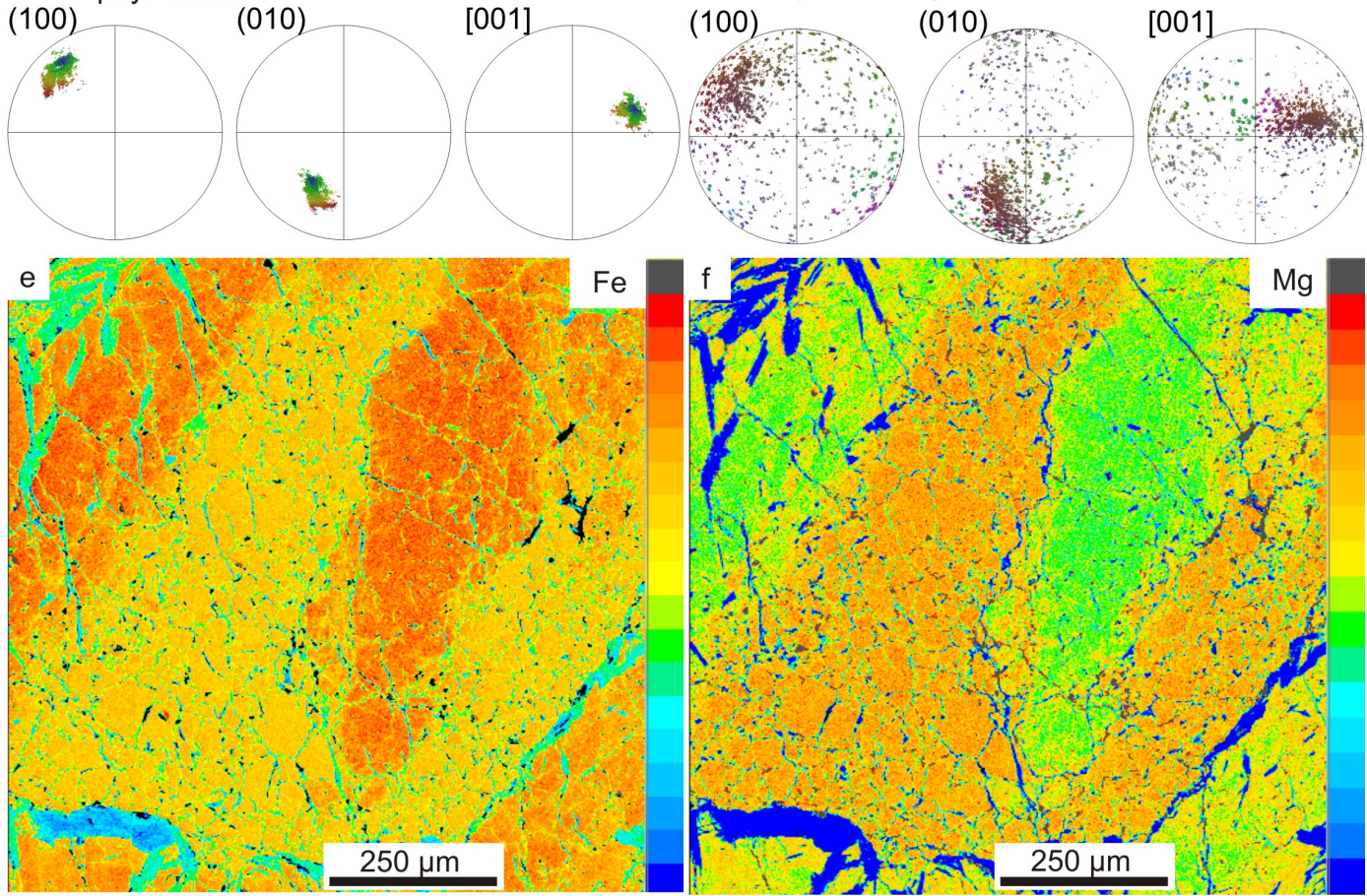

Fig. 5. (a, b) EBSD maps of partly recrystallized olivine porphyroclast (sample CT_07-13) colour-coded by relative misorientation and orientation (Euler angles), respectively. (c, d) Polefigures of poles to (100), (010) and (001) planes (equal-angle projection, lower hemisphere). (e, f) EMP maps of the same area with relative distribution of Fe (e) and $\mathrm{Mg}$ (f) (red: high content; blue: low content) showing a systematic difference of a more Fe-rich composition of new grains compared to the host porphyroclast.

the regime of dislocation creep at reasonable strain rates of $10^{-13}$ to $10^{-15} \mathrm{~s}^{-1}$ requires temperatures above about $650^{\circ} \mathrm{C}$ as based on observations from natural systems (e.g. Skrotzki et al., 1990; Altenberger, 1995; Jin et al., 1998) and the extrapolation from experimentally derived flow laws for dislocation creep of olivine (Fig. 9; Chopra and Paterson, 1981; Hirth and Kohlstedt, 2003). At the inferred range of differential stresses of 70 to $300 \mathrm{MPa}$, temperatures in the range of about $650^{\circ} \mathrm{C}$ to $800^{\circ} \mathrm{C}$ are indicated assuming reasonable strain rates of $10^{-13}$ to $10^{-15} \mathrm{~s}^{-1}$ using the flow law for dislocation creep of olivine by Chopra and Paterson (1981) (Fig. 9).

\subsection{Deformation processes and conditions recorded by the mylonitic matrix minerals}

The presence of secondary olivine (fine-grained, low $\mathrm{X}_{M g}$ ) in fine-grained aggregates together with antigorite as well as secondary pyroxene (fine-grained, no exsolution lamellae) in strain shadows (Fig. 7a-c) along the lineation $(x)$ and perpendicular to the maximum shortening direction $(z)$ indicates 

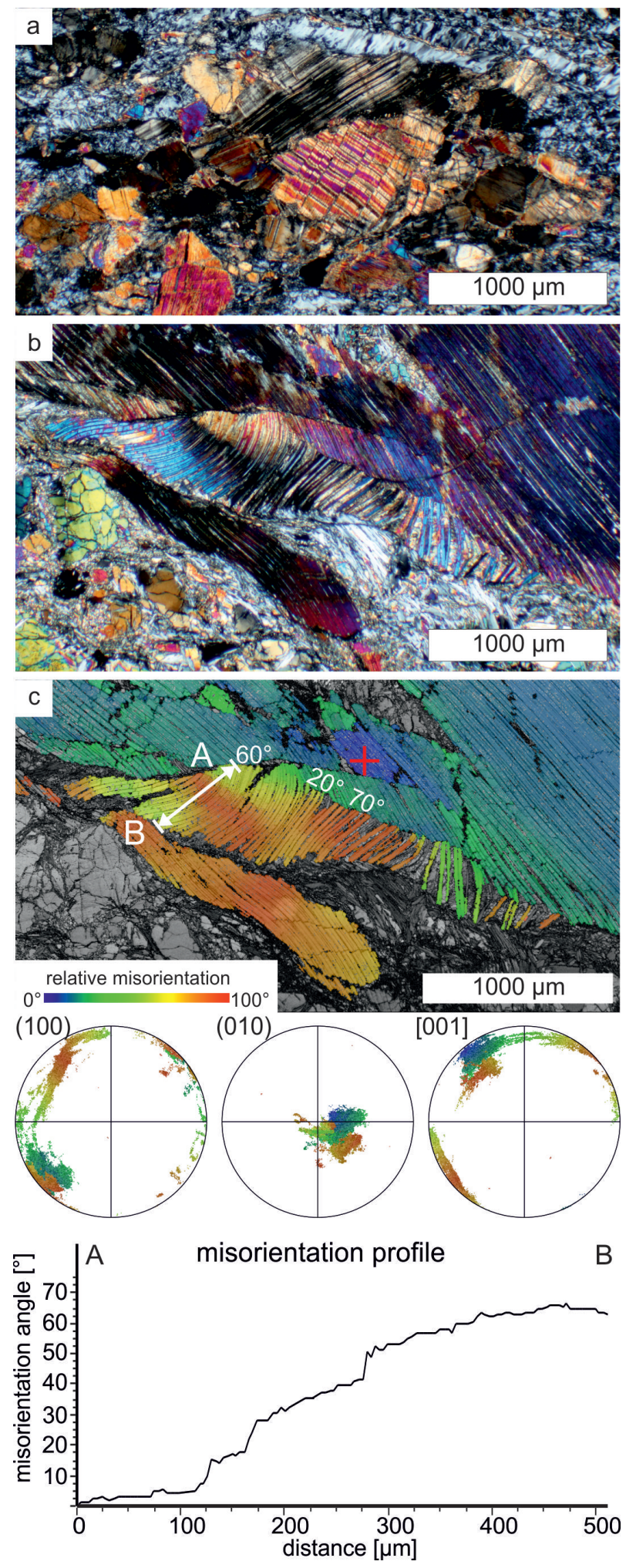

Fig. 6. (a) Polarized light micrograph (crossed polarizers) showing fractured and bent diopside porphyroclast with exsolution lamellae parallel (100) (sample CT_07-21); (b) polarized light micrograph (crossed polarizers) showing kinked and bent diopside porphyroclast with exsolution lamellae parallel (100) (sample CT_07-13); (c) EBSD map (relative misorientation to a reference point indicated by red cross) of kinked and bent diopside porphyroclast of the area shown in $\mathrm{b}$. White labelled angles give relative misorientation over kinked domains. Corresponding pole figures show dispersed (100) planes and [001] directions. The [010] axis represents the common rotation axis. White line indicates location of misorientation profile shown in (d). (d) Misorienation profile relative to the first point (a); line is indicated in the EBSD map in (c). precipitation of new material at sites of dilation from the pore fluid during deformation by dissolution-precipitation creep. The fine-grained secondary olivine enriched in crenulation cleavages and shear bands (Fig. 8a, b) indicates that olivine crystallized during folding in areas of dilation, or that olivine was present before folding and was redistributed by dissolution along the phase boundaries to antigorite. Transport in and precipitation from the pore fluid are necessary in both cases. The microstructure of secondary olivine together with antigorite in strain shadows and crenulation cleavages indicate that the phase boundaries between antigorite and olivine act as sites of preferred dissolution during dissolution-precipitation creep (Wassmann et al., 2011).

The observations from this study are in accord with previous studies on naturally deformed antigorite (e.g. Andreani et al., 2005; Auzende et al., 2006; Wassmann et al., 2011) that demonstrate the importance of dissolution-precipitation processes during ductile deformation of antigorite, especially in polyphase aggregates, where phase boundaries between antigorite and olivine act as sites of preferred dissolution. The general importance of phase boundaries as preferred sites of dissolution during dissolution-precipitation creep is evident from many natural rocks (e.g. Groshong, 1988; Knipe, 1989; Tada and Siever, 1989; Schwarz and Stöckhert, 1996, 2002; Trepmann and Stöckhert, 2009; Trepmann et al., 2010; Wassmann et al., 2011). In polyphase rocks undergoing dissolution-precipitation creep, monomineralic inclusions can deform by crystal-plastic processes as observed for folded quartz veins indicating dislocation creep within metagreywacke deformed by dissolution-precipitation creep (Trepmann and Stöckhert, 2009). The observed characteristic grain size variation in fine-grained monomineralic antigorite aggregates at sites of stress concentrations in additions to a marked CPO deflected around porphyroclasts (Fig. 8c, d) and sutured grain boundaries (Fig. 8e, f) suggest also some contribution of crystal-plastic deformation and grainboundary migration of antigorite. Auzende et al. (2006) report on sutured grain boundaries and recrystallization of antigorite from serpentinites of the Erro-Tobbio unit on the scale of high-resolution transmission electron microscopy. Antigorite deformation at low temperature (LT) is controlled by the anisotropy of the crystal structure, with dislocation glide along the antigorite (001) basal plane being a very effective deformation mechanism. The von Mises criterion, which states that five independent slip systems are required to accommodate homogenous flow of a polycrystalline material, however, has been proposed to limit the accommodation of strain by dislocation glide of antigorite (Chernak and Hirth, 2010; Hirth and Guillot, 2013). Deformation experiments on antigorite serpentinites by Hilairet et al. (2007) and Chernak and Hirth (2010) demonstrate the low strength of antigorite during ductile and semi-brittle deformation at high temperature and pressure, respectively. Hilairet et al. (2007) represent a flow law for ductile deformation of antigorite that would indicate differential stresses on the order of $5 \mathrm{MPa}$ 

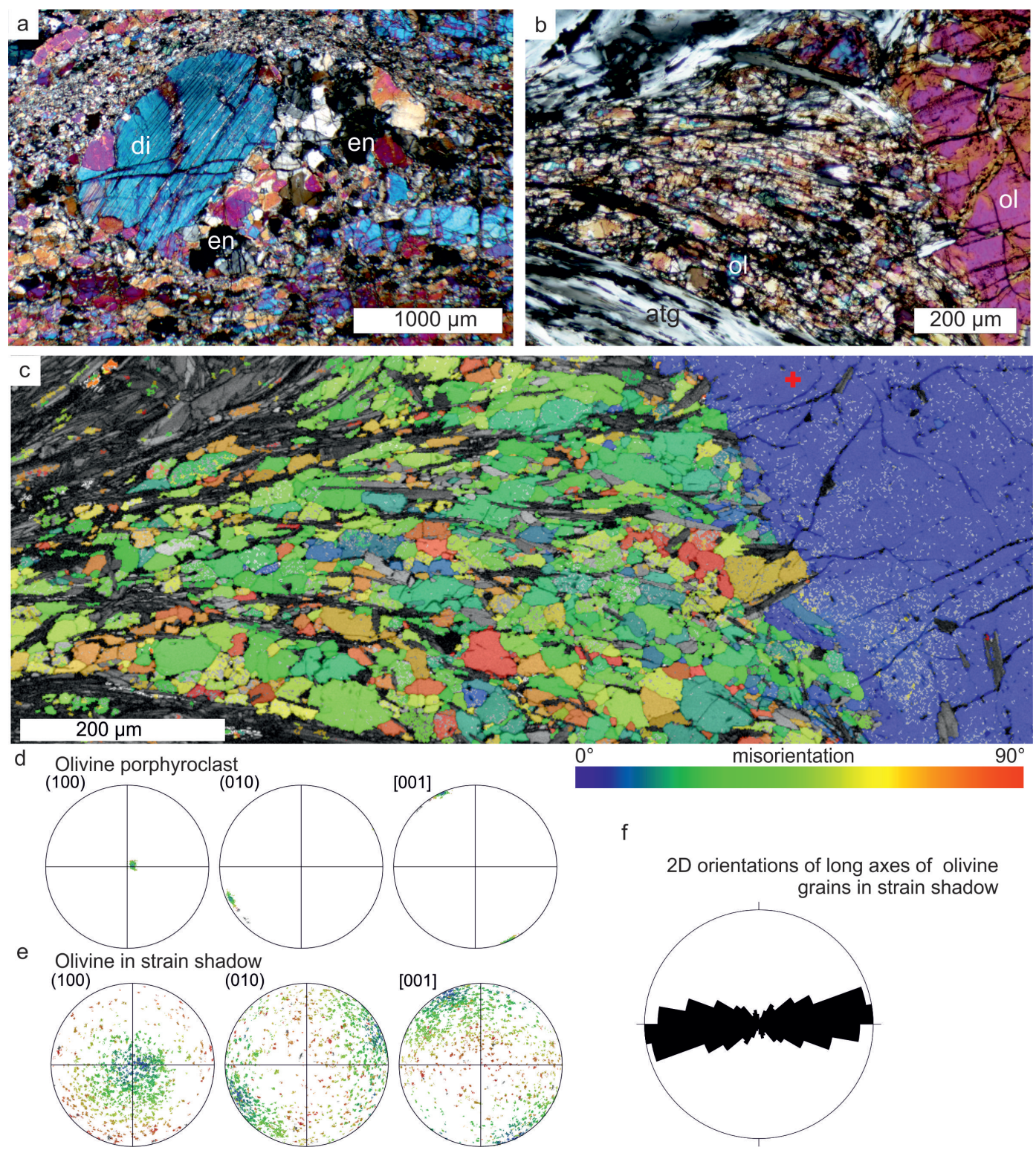

Fig. 7. (a) Polarized light micrograph (crossed polarizers) showing enstatite (en) in strain shadow around a diopside (di) porphyroclast (sample CT_07-19). Note that the new pyroxene grains in the strain shadow do not show exsolution lamellae. (b) Polarized light micrograph (crossed polarizers) showing olivine (ol) in strain shadow around olivine porphyroclast (sample CT_07-14). (c) EBSD map and corresponding pole figures of poles to (100), (010) and (001) planes of (d) olivine porphyroclast and (e) olivine in strain shadow. (f) Shape preferred orientation of olivine grains in strain shadow with long axes of grains in the foliation plane.

assuming a strain rate of $10^{-14} \mathrm{~s}^{-1}$ and $50 \mathrm{MPa}$ for a strain rate of $10^{-10} \mathrm{~s}^{-1}$. Chernak and Hirth (2010) report on semibrittle deformation with contributions of crystal-plastic deformation, and their findings likewise show a low strength of antigorite aggregates. However, these experiments have been performed at laboratory strain rates of $10^{-4} \mathrm{~s}^{-1}$ to $10^{-6} \mathrm{~s}^{-1}$.

Secondary olivine does not show indications of marked crystal-plastic deformation - as opposed to the porphyroclasts - indicating insufficiently high stresses to accumulate significant strain by dislocation creep of olivine at condi- tions at which antigorite is stable and during dissolutionprecipitation creep of the mylonitic matrix.

\subsection{From brittle and crystal-plastic deformation to dissolution-precipitation creep}

The deformation microstructures of the porphyroclasts recording dislocation creep of olivine and dislocation glide of diopside indicate upper-mantle temperature conditions (650 to $800^{\circ} \mathrm{C}$ ), i.e. considerably higher than suggested for the Alpine HP-LT metamorphism, and differential stresses of a 

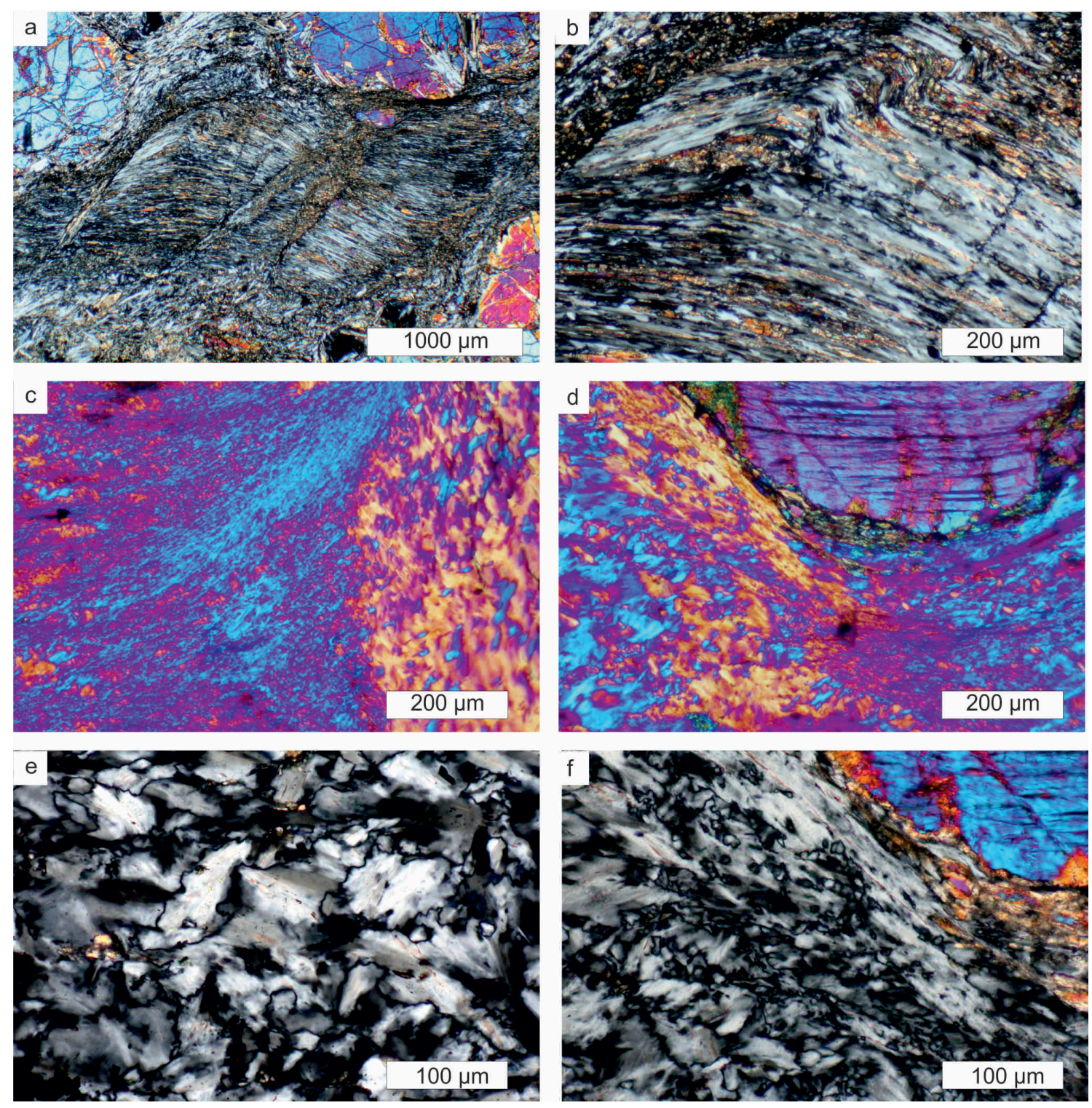

Fig. 8. Polarized light micrograph (crossed polarizers) showing antigorite microstructures. (a, b) Fine-grained folded antigorite (atg) layers forming a crenulation cleavage with fine-grained secondary olivine (ol) enriched in shear bands (sample CT_07-13). (c, d) Fine-grained antigorite aggregates (atg) with sutured grain boundaries, SPO and associated CPO deflected around porphyroclasts - photograph taken with $\lambda$-compensator plate inserted (sample CT_07-21). Note that the grain size of antigorite is very small at sites of stress concentrations. (e, f) Fine-grained antigorite aggregates with sutured grain boundaries (sample CT_07-21).

few hundred MPa are inferred (Fig. 9). Antigorite is characteristically absent in the recrystallized aggregates in olivine porphyroclasts (Figs. 3 to 5). Therefore the microstructures are interpreted to have developed in the original mantle peridotite before hydration of the peridotite and transformation into serpentinites, consistent with previous studies that report on shear zones in lherzolites from the Erro-Tobbio unit that were associated with pre-Alpine Jurassic rifting (Drury et al., 1990; Vissers et al., 1991; Hoogerduijn Strating, 1991; Hoogerduijn Strating and Vissers, 1991; Hoogerduijn Strating et al., 1993). Rifting processes are known to be associ- ated with deep earthquakes (e.g. Albaric et al., 2009; 2010; Ibs-von Seht et al., 2008). At deep continuations of seismically active fault zones peridotites can be affected by a sequence of high-stress deformation followed by recrystallization at decreasing stresses (Druiventak et al., 2011, 2012; Matysiak and Trepmann, 2012), leading to strongly heterogeneous microstructures with localized zones of fine-grained recrystallized aggregates with weak CPO within and surrounding deformed porphyroclasts. The partly recrystallized and crystal-plastically deformed olivine porphyroclasts and 


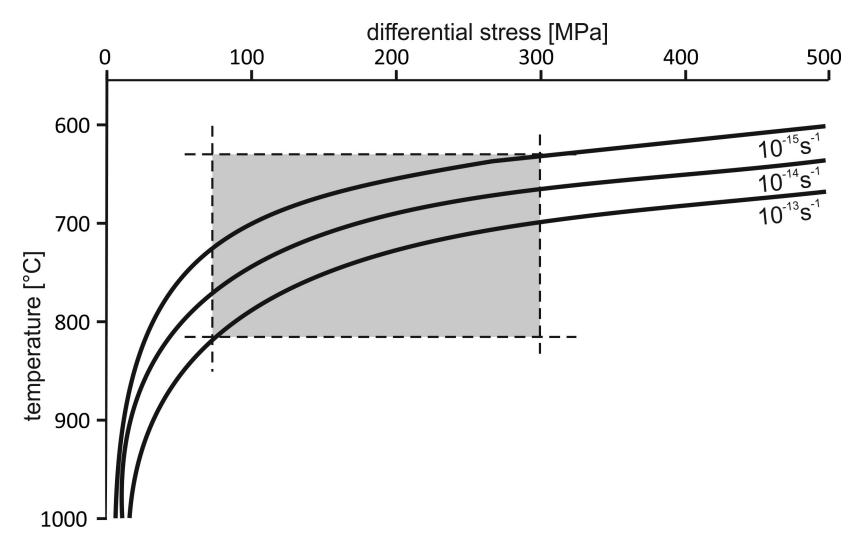

Fig. 9. Flow law for dislocation creep of olivine after Chopra and Paterson (1981). The box correlates inferred differential stresses of 70 to $300 \mathrm{MPa}$ to a temperature range of ca. 650 to $800^{\circ} \mathrm{C}$ at assumed reasonable strain rates of $10^{-13}$ to $10^{-15} \mathrm{~s}^{-1}$.

fractured, kinked and bent diopside porphyroclasts are consistent with such a microstructural record (Fig. 3-6).

The recorded dissolution-precipitation processes (Fig. 7, 8) are attributed to deformation during Alpine subduction and exhumation, consistent with previous studies (e.g. Scambelluri et al., 1991, 1995; Hermann et al., 2000; Malatesta et al., 2012a; Piccardo, 2013) - irrespective of whether the investigated partly serpentinized peridotite mylonites got serpentinized during hydration at shallow lithospheric depths, or at HP eclogite facies conditions, as discussed controversially for the Erro-Tobbio and Beigua serpentinized peridotites (Scambelluri et al., 1997; Hermann et al., 2000; Früh-Green et al., 2001; Piccardo, 2013; Scambelluri, 2013). Dissolution-precipitation creep occurred at stresses insufficient to allow for significant dislocation creep of olivine at conditions at which antigorite is stable, as secondary olivine does not show any evidence of crystal-plastic deformation. Serpentinite is commonly assumed to constitute weak material and to play a major role in the development of a subduction channel and exhumation of (U)HP metamorphic rocks (e.g. Hermann et al.,2000; Schwartz et al., 2001; Guillot et al., 2001; Auzende et al., 2006; Federico et al., 2007; Hilairet and Reynard 2009; Agard et al., 2009; Angiboust et al., 2009; Piccardo, 2013). Long-term flow with Newtonian rheology in deeper levels of subduction zones at low stress levels and low viscosities has been related to dissolution-precipitation processes in serpentinites and metasediments (e.g. Wassmann et al., 2011; Grigull et al., 2012; Wassmann and Stöckhert, 2012). Dehydration reactions of antigorite according to the reactions $(1,2)$ have been proposed to be recorded by the HP-LT metamorphic mineral assemblage of the Erro-Tobbio serpentinites (e.g. Hoogerduijn Strating and Vissers, 1991; Scambelluri et al., 1991, 2004; Ulmer and Trommsdorff, 1995; Hermann et al., 2000; Healy et al., 2009).
Antigorite + Brucite $\rightarrow$ Olivine + Water

Antigorite $\rightarrow$ Olivine + Enstatite + Water

It is suggested that fluid provided by these dehydration reactions also contributed to the recorded dissolutionprecipitation processes. If so, precipitation of secondary olivine and pyroxene from the pore fluid at sites of dilation, i.e. in strain shadows (Fig. 7a-c) and folded antigorite layers (Fig. 8a, b), might be related to these reactions. The precipitation of olivine at the expense of antigorite might then further have facilitated dissolution-precipitation processes due to the enrichment of preferred sites of dissolution, i.e. phase boundaries. Chernak and Hirth (2010) report on experiments performed at conditions above the thermal stability limit of antigorite, which document that dehydration reactions inhibit strain localization and facilitate ductile behaviour.

Generally, it is remarkable that the deformed and recrystallized olivine microstructure from the original mantle peridotites is partly preserved and not more effectively modified by serpentinization and dissolution-precipitation creep. This suggests that the serpentinized parts of the microstructure were areas of even higher strain (e.g. shear zones with recrystallized olivine of finer grain sizes) than the preserved relicts. Thus, the porphyroclasts record the minimum strain of an independent deformation event not related to the mylonitic antigorite matrix.

\section{Summary and conclusions}

The microfabrics of the investigated partly serpentinized peridotite mylonites record changing rheological behaviour during their complex geological history with a dramatic change in mineral composition from original mantle peridotite to HP-LT metamorphic serpentinites. Based on our observations the following is inferred.

(1) Brittle and crystal-plastic deformation of olivine and diopside occurred in peridotites, leading to undulatory extinction, deformation bands and intragranular recrystallized areas in olivine porphyroclasts and fragmented and kinked diopside porphyroclasts. Deformation took place at uppermantle conditions, above the thermal stability limit of antigorite, and differential stresses of a few hundred MPa. Chemical reactions during dislocation creep probably in the presence of a pore fluid are indicated by a different chemical composition of recrystallized olivine and olivine porphyroclasts. A likely geological situation for the recorded deformation is the deep area of a nearby seismically active mantle shear zone probably related to Jurassic rifting.

(2) During Alpine subduction and exhumation, dissolution-precipitation creep lead to the foliation of the partly serpentinized peridotite mylonites, formation of strain shadows and crenulation cleavages with precipitation of new olivine and pyroxene from the pore fluid at sites 
of dilation. The phase boundaries between olivine und antigorite act as sites of preferred dissolution. In contrast, in monomineralic antigorite aggregates, some contribution of crystal-plastic deformation and grain-boundary migration is suggested by sutured grain boundaries, characteristic grain size variations and a deflected combined SPO and $\mathrm{CPO}$ at sites of stress concentrations. The absence of any intragranular deformation features in newly precipitated olivine in strain shadows indicates, however, that stress conditions remained insufficiently high for significant dislocation creep of olivine at conditions at which antigorite is stable, consistent with the antigorite microstructures in the mylonitic matrix.

The deformation microstructures in olivine and diopside porphyroclasts are not associated with the matrix microstructures in the partly serpentinized peridotite mylonites but are inherited and record an independent earlier deformation event. The partly serpentinized peridotite mylonites investigated here represent an example in which the microstructural record of porphyroclasts in mylonites does not necessarily correspond to that of the mylonitic matrix but can provide information on an earlier deformation event in the geological history of the protholith.

Acknowledgements. This study has been funded by the DFG Collaborative Research Centre 526. Critical and constructive reviews by two anonymous reviewers are greatly acknowledged. We thank Bernhard Stöckhert for many stimulating discussions and constructive criticism on an earlier draft of the manuscript.

Edited by: F. Rossetti

\section{References}

Agard, P., Yamato, P., Jolivet, L., and Burov, E.: Exhumation of oceanic blueschists and eclogites in subduction zones timing and mechanisms, Earth Sci. Rev., 92, 53-79, doi:10.1016/j.earscirev.2008.11.002, 2009.

Albaric, J., Déverchère, J., Petit, C., Perrot, J., and Le Gall, B.: Crustal rheology and depth distribution of earthquakes: insights from the central and southern East African Rift System, Tectonophysics, 468, 28-41, doi:10.1016/j.tecto.2008.05.021, 2009.

Albaric, J., Perrot, J., Déverchère J., Deschamps, A., Le Gall, B., Ferdinand, R. W., Petit, C., Tiberi, C., Sue, C., and Songo, M.: Contrasted seismogenic and rheological behaviours from shallow and deep earthquake sequences in the North Tanzanian Divergence, East Africa, J. Afr. Earth Sci., 58, 799-811, doi:10.1016/j.jafrearsci.2009.09.005, 2010.

Altenberger, U.: Long-term deformation and fluid-enhanced mass transport in a Variscan peridotite shear zone in the Ivrea Zone, northern Italy: a microtextural, petrological and geochemical study of a reactivated shear zone, Int. J. Earth. Sci., 84, 591-606, 1995.

Andreani, M., Boullier, A.-M., and Gratier, J.-P.: Development of schistosity by dissolution-crystallization in a Cali- fornian serpentinite gouge, J. Struct. Geol., 27, 2256-2267, doi:10.1016/j.jsg.2005.08.004, 2005.

Angiboust, S., Agard, P., Jolivet, L., and Beyssac, O.: The ZermattSaas Ophiolite; the largest (60-km wide) and deepest (c. 70-80 $\mathrm{km}$ ) continuous slice of oceanic lithosphere detachted from a subduction zone?, Terra Nova, 21, 171-180, doi:10.1111/j.13653121.2009.00870.x, 2009.

Auzende, A. L., Guillot, S., Devouard, B., and Baronnet, A.: Serpentinites in an Alpine convergent setting: effects of metamorphic grade and deformation on microstructures, Eur. J. Mineral., 18, 21-33, doi:10.1127/0935-1221/2006/0018-0021, 2006.

Avé Lallemant, H.: Experimental deformation of diopside and websterite, Tectonophysics, 48, 1-27, 1978.

Bestmann, M. and Prior, D. J.: Intragranular dynamic recrystallization in naturally deformed calcite marble: diffusion accommodated grain boundary sliding as a result of subgrain rotation recrystallization, J. Struct. Geol., 25, 1597-1613, doi:10.1016/S0191-8141(03)00006-3, 2003.

Bodinier, J. L., Guiraud, M., Dupuy, C., and Dostal, J.: Geochemistry of basic dykes in the Lanzo Massif ( W. A.), Tectonophysics, 128, 77-95, 1986.

Büttner, S. H. and Kasemann, S. A.: Deformation-controlled cation diffusion in tourmaline: A microanalytical study on trace elements and boron isotopes, Am. Mineral., 92, 1862-1874, doi:10.2138/am.2007.2567, 2007.

Chernak, L. J. and Hirth, G.: Deformation of antigorite serpentinite at high temperature and pressure. Earth Planet. Sc. Lett., 296, 23-33, doi:10.1016/j.epsl.2010.04.035, 2010.

Chopra, P. N. and Paterson, M. S.: The experimental deformation of dunite, Tectonophysics, 78, 453-476, 1981.

Druiventak, A., Trepmann, C. A., Renner, J., and Hanke, K.: Low-temperature plasticity of olivine during high stress deformation of peridotite at lithospheric conditions; an experimental study, Earth Planet. Sc. Lett., 311, 199-211, doi:10.1016/j.epsl.2011.09.022, 2011.

Druiventak, A., Matysiak, A., Renner, J., and Trepmann, C. A.: Kick-and-cook experiments on peridotite; simulating coseismic deformation and post-seismic creep, Terra Nova, 24, 62-69, doi:10.1111/j.1365-3121.2011.01038.x, 2012.

Drury, M. R. and Urai, J. L.: Deformation-related recrystallisation process, Tectonophysics, 172, 235-253, 1990.

Drury, M. R., Hoogerduijn Strating, E. H., and Vissers, R. L. M.: Shear zones structures and microstructures in mantle peridotites from the Voltri massif, Ligurian Alps, N.W. Italy, Geologie en Mijnbouw, 69, 3-17, 1990.

Federico, L., Capponi, G., Crispini, L., Scambelluri, M., and Villa, I. M.: 39Ar/40Ar dating of high-pressure rocks from the Ligurian Alps: Evidence for a continuous subductionexhumation cycle, Earth. Planet. Sc. Lett., 240, 668-680, doi:101016/j.epsl.2005.09.062, 2005.

Federico, L., Crispini, L., Scambelluri, M., and Capponi, G.: Ophiolite mélange zone records exhumation in a fossil subduction channel, Geology, 35, 499-502, doi:10.1130/G23190A.1, 2007.

Früh-Green, G. L., Scambelluri, M., and Vallis, F.: O-H isotope ratios of high pressure ultramafic rocks: implications for fluid sources and mobility in the subducted hydrous mantle, Contri. Mineral. Petrol., 141, 145-159, doi:10.1007/s004100000228, 2001. 
Gao, J., John, T., Klemd, R., and Xiong, X.: Mobilization of Ti-Nb-Ta during subduction: Evidence from rutile-bearing dehydration segregations and veins hosted in eclogite, Tianshan, NW China, Geochim. Cosmochim. Ac., 71, 4974-4996, doi:10.1016/j.gca.2007.07.027, 2007.

Green II, H. W. and Radcliffe, S. V.: Deformation Processes in the Upper Mantle, Geophys. Monogr., 16, 139-156, 1972.

Grigull, S., Krohe, A., Moos, C., Wassmann, S., and Stöckhert, B.: "Order from chaos": A field-based estimate on bulk rheology of tectonic mélanges formed in subduction zones, Tectonophysics, 568-569, 86-101, 2012.

Groshong Jr., R. J.: low-temperature deformation mechanisms and their interpretation, Geol. Soc. Am. Bull., 100, 1329-1360, 1988.

Guillot, S., Hattori, K. H., de Sigoyer, J., Naegler, T., and Auzende, A.-L.: Evidence of hydration of the mantle wedge and its role in the exhumation of eclogites, Earth Planet. Sc. Lett., 193, 115127, doi:10.1016/D0012-821X(01)00490-3, 2001.

Handy, M. R., Wissing, S. B., and Streit, L. E.: Frictional-viscous flow in mylonite with varied bimineralic composition and its effect on lithospheric strength, Tectonophysics, 303, 175-191, 1999.

Healy, D., Reddy, S. M., Timms, N. E., Gray, E. M., and Brovarone, A. V.: Trench-parallel fast axes of seismic anisotropy due to fluid-filled cracks in subducting slabs, Earth Planet. Sc. Lett., 283, 75-86, doi:10.1016/j.eps1.2009.03.037, 2009.

Hermann, J., Müntener, O., and Scambelluri, M.: The importance of serpentinite mylonites for subduction and exhumation of oceanic crust, Tectonophysics, 327, 225-238, 2000.

Hilairet, N., Reynard, B., Wang, Y., Daniel, I., Merkel, S., Nishiyama, N., and Petitgirard, S.: High-pressure creep of serpentinite, interseismic deformation, and initiation of subduction, Science, 318, 1910-1913, doi:10.1126/science.1148494, 2007.

Hilairet, N. and Reynard, B.: Stability and dynamic of serpentinite layer in subduction zone, Tectonophysics, 465, 24-29, doi:10.1016/j.tecto.2008.10.005, 2009.

Hirth, G. and Kohlstedt, D.: Rheology of the upper mantle and the mantle wedge: a view from the experimentalists, in: The Subduction Factory, edited by: Eiler, J., Geoph. Monogr. Series, American Geophysical Union, 138, 83-105, 2003.

Hirth, G. and Guillot, S.: Rheology and tectonic significance of serpentinite, Elements, 9, 107-113, doi:10.2113/gselements.9.2.107, 2013.

Hoogerduijn Strating, E. H. and Vissers, R. L. M.: Dehydrationinduced fracturing of eclogite-facies peridotites: implications for the mechanical behavior of subducting oceanic lithosphere, Tectonophysics, 200, 187-198, 1991.

Hoogerduijn Strating, E. H.: Extensional faulting in an intraoceanic subduction complex - working hypothesis for the Palaeogene of the Alps - Apennine system, Tectonophysics, 238, 255-273, 1994.

Hoogerduijn Strating, E. H., Rampone, E., Piccardo, G. B., Drury, M. G., and Vissers, R. L. M.: Subsolidus emplacement of mantle peridotites during incipient oceanic rifting and opening of the Mesozoic Tethys (Voltri Massif, NW Italy), J. Petrol., 34, 901-927, 1993.

Ibs-von Seht, M., Plenefisch, T., and Klinge, K.: Earthquake swarms in continental rifts - a comparison of selected cases in America, Africa and Europe, Tectonophysics, 452, 66-77, doi:10.1016/j.tecto.2008.02.008, 2008.
Ingrin, J., Doukhan, N., and Doukhan, J.: Dislocation glide systems in diopside single crystals deformed at $800-900^{\circ} \mathrm{C}$, Eur. J. Mineral., 4, 1291-1302, 1992.

Jin, D., Karato, S.-I., and Obata S-I.: Mechanisms of shear localization in the continental lithosphere: inference from the deformation microstructures of peridotites from the Ivrea zone, northwestern Italy, J. Struct. Geol., 20, 195-209, 1998.

Jung, H. and Karato, S.-I.: Effects of water on dynamically recrystallized grain-size of olivine, J. Struct. Geol., 23, 1337-1344, doi:10.1016/S0191-8141(01)00005-0, 2001.

Jung, H., Katayama, I., Jiang, Z., Hiraga, T., and Karato, S.: Effect of water and stress on the lattice-preferred orientation of olivine, Tectonophysics, 421, 1-22, doi:10.1016/j.tecto.2006.02.011, 2006.

Karato, S.-I., Toriumi, M., and Fujii, T.: Dynamic recrystallization of olivine single crystals during high-temperature creep, Geophys. Res. Lett., 7, 649-652, 1980.

Kirby, S. H. and Christie, J. M.: Mechanical twinning in diopside $\mathrm{Ca}(\mathrm{Mg}, \mathrm{Fe}$ ) Si (sub 2) O (sub 6); structutal mechanism and associated crystal defects, Phys. Chem. Miner., 1, 137-163, 1977.

Knipe, R. J.: Deformation mechanisms; recognition from natural tectonites, J. Struct. Geol., 11, 127-146, 1989.

Kolle, J. J. and Blacic, J. D.: Deformation of single-crystal clinopyroxenes; 1, Mechanical twinning in diopside and hedenbergites, J. Geophys. Res., 87, 4019-4034, 1982.

Lloyd, G. E. and Freeman, B.: Dynamic recrystallization of quartz under greenschist consitions, J. Struct. Geol., 16, 867-881, 1994

Malatesta, C., Crispini, L., Federico, L., Capponi, G., and Scambelluri, M.: The exhumation of high pressure ophiolites (Voltri Massif, Western Alps): Insights from structural and petrological data on metagabbro bodies, Tectonohysics, 568-569, 102-123, doi:10.1016/j.tecto.2011.08.024, 2012a.

Malatesta, C., Gerya, T., Scambelluri, M., Federico, L., Crispini, L., and Capponi, G.: Intraoceanic subduction of "heterogeneous" oceanic lithosphere in narrow basins: 2-D numerical modelling, Lithos, 140-141, 234-251, doi:10.1016/j.lithos.2012.01.003, 2012b.

Manatschal, G., Müntener, O., Lavier, L. L., Minshull, T. A., and Péron-Pinvidic, G.: Observations from the Alpine Tethys and Iberia-Newfoundland margins pertinent to the interpretation of continental breakup, in: Imaging, mapping and modelling continental lithosphere extension and breakup, edited by: Karner, G. D., Manatschal., G., and Pinheiro, L. M., Geol. Soc. Lond., Special Punblications, 282, 291-324, 2007.

Mancktelow, N. S. and Pennacchioni, G.: The influence of grain boundary fluids on the microstructure of quartz-feldspar mylonites, J. Struct. Geol., 26, 47-69, doi:10.1016/S01918141(03)00081-6, 2004.

Matysiak, A. K. and Trepmann, C. A.: Crystal-plastic deformation and recrystallization of peridotite controlled by the seismic cycle, Tectonophysics, 530-531, 111-127, doi:101016/j.tecto.2011.11.029, 2012.

Messiga, B., Scambelluri, M., and Piccardo, G. B.: Chloritoidbearing assemblages in mafic systems and eclogite-facies hydration of alpine $\mathrm{Mg}$-Al metagabbros (Erro-Tobbio Unit, Ligurian Western Alps), Eur. J. Mineral., 7, 1149-1167, 1995.

Mitra, G.: Ductile deformation zones and mylonites: the mechanical processes involved in the deformation of crystalline basement rocks, Am. J. Sci., 278, 1057-1084, 1978. 
Moghadam, R. H., Trepmann, C. A., Stöckhert, B., and Renner, J.: Rheology of synthetic omphacite aggregates at high pressure and high temperature, J. Petrol., 51, 921-945, doi:10.1093/petrology/egq006, 2010.

Müller, W. F. and Franz, G.: TEM-microstructures in omphacite and other minerals from eclogite near to a thrust zone; the Eclogite Zone - Venediger nappe area, Tauern Window, Austria, Neues Jahrbuch fuer Mineralogie Abhandlungen, 184, 285-298, doi:10.1127/0077-7757/2008/0099, 2008.

Nicolas, A. and Poirier, J. P.: Crystalline Plasticity and Solid State Flow in Metamorphic Rocks, John Wiley and Sons, London, 444 p, 1976.

Orzol, J., Trepmann, C. A., Stöckhert, B., and Shi, G.: Critical shear stress for mechanical twinning of jadeite; an experimental study, Tectonophysics, 372, 135-145, doi:10.1016/S00401951(03)00242-7, 2003.

Orzol, J., Stöckhert, B., Trepmann, C. A., and Rummel, F.: Experimental deformation of synthetic wet jadeite aggregates, J. Geophys. Res., 111, doi:10.1029/2005JB003706, 2006.

Péron-Pinvidic, G. and Manatschal, G.: The final rifting evolution at deep magma-poor passive margins from Iberia-Newfoundland: A new point of view, Int. J. Earth. Sci., 98, 1581-1597, doi:10.1007/s00531-008-0337-9, 2009.

Piccardo, G. B.: Mantle processes during ocean formation: Petrologic records in peridotites from the Alpine-Apennine ophiolites, Episodes, 26, 193-199, 2003.

Piccardo, G. B.: The Jurassic Ligurian Tethys, a fossil ultra-slow spreading ocean: The mantle perspective, in: Metasomatism in oceanic and continental lithospheric mantle, edited by: Coltorti, M. and Grogoire, M., Geol. Soc. Lond., Special Publications, 294, 11-33, 2008.

Piccardo, G. B.: The evolution of the lithospheric mantle during Mesozoic rifting in the Ligure-Piedmontese domain, Journal of the Virtual Explorer, Electronic Edition, 36, paper 7, 2010.

Piccardo, G. B.: Subduction of a fossil slow-ultraslow spreading ocean: a petrology-constrained geodynamic model based on the Voltri Massif, Ligurian Alps, Northwest Italy, Int. Geol. Rev., 55, 787-803, doi:10.1080/00206814.2012.746806, 2013.

Piccardo, G. B. and Vissers, R. L. M.: The pre-oceanic evolution of the Erro-Tobbio peridotites (Voltri Massif, Ligurian Alps, Italy), J. Geodyn., 43, 417-449, doi:10.1016/j.jog.2006.11.001, 2007.

Piepenbreier, D. and Stöckhert, B.: Plastic flow of omphacite in eclogites at temperatures below $500^{\circ} \mathrm{C}$ - implications for interplate coupling in subduction zones, Int. J. Earth Sci., 90, 197210, 2001

Poirier, J.-P.: Creep of crystals - High temperature deformation processes in metals, ceramics and minerals, Cambridge University press, Cambridge, 260 p, 1985.

Prior, D. J., Trimby, P. W., Weber, U. D., and Dingley, D. J.: Orientation contrast imaging of microstructures in rocks using forescatter detectors in the scanning electron microscope, Mineral. Mag., 60, 859-869, 1996.

Prior, D. J., Boyle, A. P., Brenker, F., Cheadle, M. C., Day, A., Lopez, G., Peruzzi, L., Potts, G., Reddy, S., Spiess, R., Timms, N. E., Trimby, P., Wheeler, J., and Zetterstrom, L.: The application of electron backscatter diffraction and orientation contrast imaging in the SEM to textural problems in rocks, Am. Mineral., 84, 1741-1759, 1999.
Raimbourgh, H., Toyoshima, T., Harima, Y., Kimura, G.: Grain-size reduction mechanisms and rheological consequences in hightemperature gabbro mylonites of Hidaka, Japan, Earth Planet. Sci., 267, 637-653, 2008.

Raleigh, C. B. and Talbot, J. L.: Mechanical twinning in naturally and experimentally deformed diopside, Am. J. Sci., 265, 151$165,1967$.

Rampone, E., Romairone, A., and Hofmann, A.: Contrasting bulk and mineral chemistry in depleted mantle peridotites: evidence for reactive porous flow, Earth. Planet. Sc. Lett., 218, 491-506, doi:10.1016/S0012-821X(03)00679-4, 2004.

Rampone, E., Romairone, A., Abouchami, W., Piccardo, G. B., and Hofmann, A. W.: Chronology, petrology and isotope geochemistry of the Erro-Tobbio Peridotites (Ligurian Alps, Italy): Records of late Palaeozoic lithopheric extension, J. Petrol., 46, 799-827, doi:10.1093/petrology/epi001, 2005.

Rubatto, D. and Scambelluri, M.: U-Pb dating of magmatic zircon and metamorphic baddeleyite in the Ligurian eclogites (Voltri Massif, Western Alps), Contrib. Mineral. Petrol., 146, 341-355, doi:10.1007/s00410-003-0502-x, 2003.

Scambelluri, M.: Comments on the paper "Subduction of a fossil slow-ultraslow spreading ocean: a petrology-constained geodynamic model based on the Voltri Massif, Ligurian Alps, NW Italy" by G. B. Piccardo, Int. Geol. Rev., 55, 804-811, doi:10.1080/00206814.2013.780367, 2013.

Scambelluri, M., Hoogerduijn Strating, E. H., Piccardo, G. B., Vissers, R. L. M., and Rampone, E.: Alpine olivine- and titanian clinohumite-bearing assemblages in the Erro-Tobbio peridotite (Voltri Massif, NW Italy), J. metamorph. Geol., 9, 79-91, 1991.

Scambelluri, M., Müntener, O., Hermann, J., Piccardo, G. B., and Trommsdorff, V.: Subduction of water into mantle: History of an Alpine peridotite, Geology, 23, 459-462, 1995.

Scambelluri, M., Piccardo, G.B., Philippot, P., Robbiano, A. and Negretti, L.: High salinity fluid inclusion formed from recycled seawater in deeply subducted alpine serpentinite, Earth Planet. Sc. Lett., 148, 485-499, 1997.

Scambelluri, M., Müntener, O., Ottolini, L., Pettke, T. T., and Vannucci, $\mathrm{R}$. : The fate of $\mathrm{B}, \mathrm{Cl}$ and $\mathrm{Li}$ in the subducted oceanic mantle and in the antigorite breakdown fluids, Earth Planet. Sc. Lett., 222, 217-234, doi:10.1016/j.epsl.2004.02.012, 2004.

Schmid, S. M. and Handy, M. R.: Towards a genetic classification of fault rocks: geological usage and tectonophysical implications, in: Hsii, K. J., Mackenzie, J., and Mtiller, D., Controversies in Modern Geology, Academic Press, London, 339-362, 1990.

Schwartz, S., Allemand, P., and Guillot, S.: Numerical model of the effect of serpentinites on the exhumation of eclogitic rocks: insights from the Monviso ophiolitic massif (Western Alps), Tectonophysics, 342, 193-206, doi:10.1016/D00401951(01)00162-7, 2001.

Schwarz, S. and Stöckhert, B.: Pressure solution in siliciclastic HPLT metamorphic rocks; constraints on the state of stress in deep levels of accretionary complexes, Tectonophysics, 255, 203-209, 1996.

Skemer, P., Katayama, I., and Karato, S.-I.: Deformation fabrics of the Cima di Gagnone peridotite massif, Central Alps, Switzerland; evidence of deformation at low temperature in the presence of water, Contrib. Mineral. Petrol., 152, 43-51, doi:10.1007/s00410-006-0093-4, 2006. 
Skrotzki, W., Wedel, A., Weber, K., and Müller, W. F.: Microstructure and texture in lherzolites of the Balmuccia massif and their significance regarding the thermomechanical history, Tectonophysics, 179, 227-251, 1990.

Stöckhert, B.: Stress and deformation in subduction zones: insight from the record of exhumed metamorphic rocks, Geol. Soc. Sp., 200, 255-274, 2002.

Stünitz, H.: Syndeformational recrystallization \pm dynamic or compositionally induced?, Contrib. Mineral. Petrol., 131, 219-236, 1998.

Tada, R. and Siever, R.: Pressure solution during diagenesis, Annu. Rev. Earth P. Sc., 17, 89-118, 1989.

Trepmann, C. A. and Stöckhert, B.: Mechanical twinning of jadeite - an indication of synseismic loading beneath the brittle-ductile transition, Int. J. Earth Sci, 90, 4-13, 2001.

Trepmann, C. A. and Stöckhert, B.: Quartz microstructures developed during non-steady state plastic flow at rapidly decaying stress and strain rate, J. Struct. Geol., 25, 2035-2051, doi:10.1016/S0191-8141(03)00073-7, 2003.

Trepmann, C. A. and Stöckhert, B.: Microfabric of folded quartz veins in metagreywackes: dislocation creep and subgrain rotation at high stress, J. metamorph. Geol., 27, 555-570, doi:10.1111/j.1525-1314.2009.00842.x, 2009.

Trepmann, C. A., Stöckhert, B., Dorner, D., Moghadam, R. H., Küster, M., and Röller, K.: Simulating coseismic deformation of quartz in the middle crust and fabric evolution during postseismic stress relaxation; an experimental study, Tectonophysics, 442, 83-104, doi:10.1016/j.tecto.2007.05.005, 2007.

Trepmann, C. A., Lenze, A., and Stöckhert, B.: Static recrystallization of vein quartz pebbles in a high pressure - low temperature metamorphic conglomerate, J. Struct. Geol., 32, 202-215, doi:10.1016/j.jsg.2009.11.005, 2010.

Tribuzio, R., Tiepolo, M., and Vannucci, R.: Evolution of gabbroic rocks of the Northern Apennine ophiolites (Italy): Comparison with the lower oceanic crust from modern slow-spreading ridges, in: Ohiolites and oceanic crust: New insights from field studies and the Ocean Drilling Program, edited by: Dilek, Y., Moores, E. M., Elthon, D., and Nicolas, A., Boulder, CO, Geol. S. AM. S., 349, 129-138, 2000.

Ulmer, P. and Trommsdorff, V.: Serpentine stability to mantle depths and subduction-related magmatism, Science, 268, 858861,1995
Urai, J. L., Means, W. D., and Lister, G. S.: Dynamic recrystallization of minerals, Geoph. Monogr. Series, 36, 161-199, 1986.

Van der Wal, D., Chopra, P., Drury, M., and Fitz Gerald, J.: Relationship between dynamic recrystallized grain size and deformation conditions in experimentally deformed olivine rocks, Geophys. Res. Lett., 20, 1479-1482, 1993.

Vignaroli, G., Rossetti, F., Rubatto, D., Theye, T., Lisker, F., and Phillips, D.: Pressure-temperature-deformation-time (P-T-dt) exhumation history of the Voltri Massif HP complex, Ligurian Alps, Italy, Tectonics, 29, TC6009, doi:10.1029/2009TC002621, 2010.

Vissers, R. L. M., Drury, M. R., Hoogerduijn Strating, E. H., and van der Wal, D.: Shear zones in the upper mantle - a case study in an Alpine lherzolite massif, Geology, 19, 990-993, 1991.

Vissers, R. L. M., Drury, M. R., Hoogerduijn Strating, E. H., Spiers, C. J., and van der Wal, D.: Mantle shear zones and their effect on lithosphere strength during coninental breakup, Tectonophysics, 249, 155-171, 1995.

Wassmann, S. and Stöckhert, B.: Matrix deformation mechanisms in HP-LT tectonic melanges; microstructural record of jadeite blueschist from the Franciscan Complex, California, Tectonophysics, 568-569, 135-153, doi:10.1016/j.tecto.2012.01.009, 2012.

Wassmann, S., Stöckhert B., and Trepmann, C. A.: Dissolution precipitation creep versus crystalline plasticity in high pressure metamorphic serpentinites, Geol. Soc., London, Special Publications, 360, 129-149, 2011.

White, S. H., Burrows, S. E., Carreras, J., Shaw, N. O., and Humphreys, F. J.: On mylonites in ductile shear zones, J. Struct. Geol., 2, 175-187, 1980.

Yund, R. A. and Tullis, J.: Compositional changes of minerals associated with dynamic recrystallization, Contrib. Mineral. Petrol., 108, 346-355, 1991.

Zhang, J. and Green, H. W.: Experimental investigation of eclogite rheology and its fabrics at high temperature and pressure, J. Metamorph. Geol., 25, 97-115, doi:10.1111/j.15251314.2006.00684.x, 2007.

Zhang, S., Karato, S.-I., FitzGerald, J., Faul, U., and Zhou, Y.: Simple shear deformation of olive aggregates, Tectonophysics, 316, 133-152, 2000.

Zhang, J., Green II, H. W., and Bozhilov, K. N.: Rheology of omphacite at high temperature and pressure and significance of its lattice preferred orientations, Earth Planet. Sc. Lett., 246, 432443, doi:10.1016/j.eps1.2006.040.006, 2006. 